\title{
SPEAKING PROBLEMS OF EFL STUDENTS AT ENGLISH EDUCATION STUDY PROGRAM IN MUHAMMADIYAH LUWUK UNIVERSITY
}

\author{
ST. Marhana Rullu' ${ }^{1}$ Hamia Daburan ${ }^{2}$ \\ ${ }^{1}$ PBI FKIP UM Luwuk, ${ }^{2}$ PBI FKIP UM Luwuk \\ Email: sitimarhanarullu1991@gmail.com ${ }^{1}$, hamia_niank@yahoo.co.id²
}

\begin{abstract}
Abstrak
Penelitian ini menekankan pada masalah kemampuan berbicara dalam bahasa Inggris pada mahasiswa pendidikan Bahasa Inggris di Universitas Muhammadiyah Luwuk. Jenis penelitian ini adalah kualitatif deskriptif. Pada penelitian ini peneliti menggunakan instrumen wawancara untuk mengetahui masalah apa yang dihadapi mahasiswa sehingga sulit untuk menggunakan Bahasa Inggris. Dari hasil penelitian, peneliti menemukan masalah utama yang mereka hadapi yakni keterbatasan pada kosa kata, kesalahan pada pelafalan kata-kata, dan tata bahasa yang kurang tepat. Selain itu, mahasiswa juga mengalami perasaan cemas ketika berbicara menggunakan Bahasa Inggris dan malu ketika salah dalam berbicara, serta masih terpengaruh dengan bahasa ibu mereka sehingga mereka bermasalah dalam berbicara dalam Bahasa Inggris.
\end{abstract}

Kata kunci: Berbicara; Masalah dalam Berbicara.

\section{Abstract}

This research emphasized the problems of speaking ability in English among students of English Education Study Program in Muhammadiyah Luwuk University. This type of research was descriptive qualitative. In this research, the researcher used interview as instrument to find out the problems faced by the students in speaking English. From the results of the research, the researcher found the main problems faced by the students were limitations on vocabulary, errors in pronunciation, and incorrect grammar. In addition, the students also got anxiety when they speak in English and they embarrassed when they speak incorrectly, and they are still affected by their native language until they have problems in speaking English.

Keywords: Speaking; Speaking Problems. 


\section{Introduction}

Today English is extensively used by various groups in Indonesia. Entering the globalization era, many places are found both in private and regular courses. This trend of English globalization, as a worldwide phenomenon, makes it necessary to communicate with people from different linguistic. The majority of English users can be found in countries where the language is used as second or foreign language. In Indonesia, English is a foreign language that is studied at various levels in schools. From the level of Elementary School, junior School to High School until University. Teaching English in Indonesia focuses on the ability of communication.

Speaking is not only the basic aspect to get when learning language but also it is very important in everyday life. It is caused that when people meet, people exchange greetings, small talk, recount recent experiences, and people to be able to establish a comfortable zone in interaction with others. Most of people learning language has a goal to be able to speak so that they can communicate well. This reinforces that speaking as communication skill are very important in establishing good relationship with other, and will affect in all aspects in life.

Richard and Renandya (2002) stated that speaking is considered to be the most important language skill. It means that speaking used in every area, such as to describe something, to make request, to complain about people's behavior, to give some information or to entertain people. In addition, Zhang (2009) employed that speaking still the most difficult skill to master for the EFL students and they felt afraid to make some mistakes when they speak English for communicating. It is caused that speaking as the process of building and sharing meaning, producing and receiving information through verbal and non-verbal in various contexts.

To express the ideas well, EFL students should be encouraged to learn independently, they should be equipped with vocabulary, grammar, pronunciation, fluency, and comprehension. Burnkart (1998) confirmed that EFL students have to know three areas of knowledge involved within speaking namely (1) mechanics of language elements (pronunciation, vocabulary, grammar) which emphasize on use of right words in the right order with the pronunciation, (2) the functions of language that deals with speaking performance in the form transaction and interaction, (3) the sociocultural norms (consist of as turn taking, rate of speech). When EFL students speak, they construct their idea and their perception in words, they tell their feelings so that the interlocutors get the information what they mean. Furthermore, speaking as an oral expression involves not only in using the right pattern of rhythm and intonation, but also the right order in conveying the right meaning.

Speaking English is the most elements that must be master to by foreign language especially the EFL students at university. Some universities have made English a priority, they conducted debate competition and speech to make the EFL students more active in speaking English when they communicate with others. However, not all EFL students can active in speaking because they lack necessary of knowledge. Besides that, some of EFL students do not have confidence to speak English in interacting, they feel afraid to make mistake in pronunciation, so that they feel there is not to say. Less motivation is also problems for EFL students in speaking English, so that it makes them passive in communicating with their friends or their lecture. Furthermore, the EFL students are still influenced by their mother tongue or first language, so that they worry because their English is not good as native speakers. In line with this explanation, according to Ur (1996) there are some speaking problem that the EFL students faced, these are: inhibition, nothing to say, low or uneven participation and mother tongue use. 
Thornbury (2005) confirms that the main speaking problems of EFL students face two factors; knowledge factors and skill factors. Knowledge factors are EFL students do not understand the language element that able to produce their language, such as EFL students must understand about the communicative competence. Skill factors are EFL students' ability is not automatically ascertain about the pronunciation, mechanics, or fluency. Therefore, the EFL students should know and master both of the factors so that they can speak English well. However, not all EFL students after studying English can communicate using English accurately and fluently.

Other problems in speaking that appear in EFL students are clustering, reduced forms, performance variables, and colloquial language (Brown, 2001). Clustering means that the EFL students can organize their speech together not word by word. Reduced forms, here were all about special problems in teaching spoken English such as contractions, elisions, reduced vowel, etc. Performance variables, EFL students have to learn how to pause and hesitate so that it can allow them to think about what to talk next. They can add fillers such as um, well, I mean, you know, etc. to manifest a certain number of performance hesitations. Colloquial language, the EFL students should know about idioms, slang and phrases of colloquial language and they can practice in using all the forms.

Some researchers have conducted research on speaking problems of EFL students. Sayuri (2016) conducted a research about English speaking problems of EFL Learners of Mulawarman University. In his research, he found that the EFL learners faced the speaking problems were having limited knowledge on the element of speaking skill such as vocabulary, grammar, pronunciation, and fluency. Furthermore, the EFL students have own personal reasons including lack of motivation, lack of confidence, lack of practice and shy to perform speaking. According to Heriansyah (2012), many EFL students often no idea about what to say, they are shy and uncomfortable if make mistakes, the EFL students also afraid making errors and will be laughed by their friends, they are not used English since their vocabulary and pronunciation are poor.

From the explanation above, we can conclude that the EFL students face difficulties in speaking English that are related shyness, no motivation, lack of confidence and poor pronunciation. The objective of this research was to investigate the speaking problem faced by the EFL students of English Education Study Program in Muhammadiyah Luwuk University.

\section{Research Method}

In this research, the researcher used qualitative descriptive method. This research was conducted at English Education Study Program of Teacher and Education Faculty in Muhammadiyah Luwuk University. The research subjects were all the EFL students in third semester at the English Education Study Program who got the lowest grades in speaking class. They were taking academic oral skill (speaking) and many of them had low performance in speaking class. The selection of research subject was done by selecting EFL students who got grade $\mathrm{C}$ or the lowest passing grade in general speaking course in the second semester and also based on information from the lecturer about the EFL students who had low performance in speaking class at the third semester.

In this research, the researcher used interview as instrument for collecting the data. Interview was conducted to get the important information from the EFL students related the problem in speaking English. In interview section, the researcher provided some items to ask in interview. In other word, the researcher made some probing questions in interview concerning the goal of this research. The EFL students were asked about their difficulties/problem in speaking, the factor causing difficulties in English, and their 
efforts to overcome their problem in speaking. Moreover, the researchers asked some question dealing with the obtained data.

The data collected from interview were analyzed by using interactive model of data analysis consisting of three concurrent flows of activity: data reduction, data display, and drawing conclusion/verification (Miles and Huberman, 1994). The data form interview was transcribed and sorted into transcription interview. After that, the data were displayed on narrative text, to draw conclusions from the mass of data. The last taking conclusion from the displayed data based on objective research.

\section{Findings and Discussion}

In this section presents the findings and discussion. It can be supplemented by tables, graphs (figures), and/or chart. In the discussion presents the result of the data that establishing at the finding, and linking with relevant sources.

From the interview that had been conducted, the researcher found some problems in speaking are faced by the EFL students of English Education Study Program in Muhammadiyah Luwuk University. Specifically, the detail problems can be seen as follows:

a. Lack of vocabulary

The most problem faced by EFL students was lack of vocabulary. They assumed that vocabulary is the first problem encountered when speaking English. The following are excerpts pertaining to the problem faced by the EFL students.

Students 1: Kadang saya ingin menggunakan bahasa Inggris ketika berbicara dengan teman-teman tetapi kata-kata yang saya miliki terbatas, sehingga saya hanya berbicara menggunakan bahasa inggris yang saya ketahui dan menggunakan bahasa Indonesia selebihnya.

Students 1: Sometimes I want to use English when talking with friends but my vocabularies are limited. Therefore, I only speak English that I know and use Indonesian that I don't know.

From the students' utterance can be concluded that the first problem faced by EFL students are lack of vocabulary. In speaking English, without having enough vocabulary the students cannot communicate well. Lack of vocabulary is very disturbing in English speaking, without mastery the words or vocabulary, they impossible to speak each other's.

\section{b. Pronunciation}

Pronunciation itself is how to pronounce or make the correct sound when mentioning a word. One of the problems faced by the students was worried about making mistakes in pronunciation. It is clearly shown in the following extraction:

Students 2: Saya sulit untuk menyebutkan kata-kata dalam bahasa Inggris dengan baik dan benar dan sering keliru dalam pengucapan sehingga itu membuat saya merasa malu.

Students 2: I find it so hard to pronounce words in English properly and I often make mistakes in pronouncing the vocabulary. So that, its' makes me feel ashamed.

Pronunciation is very dominant problems faced in communicating English. It is caused by EFL students have cultural backgrounds and languages of their perspective regions, so that it is difficult for them to pronounce words in English.

c. Grammar

The next problem faced by EFL students was worry about making mistakes in grammar. Grammar is one of the difficulties in speaking based on the interview. This result derives from the students' statement in interview below: 
Students 3: Saya bermasalah dalam grammar, saya selalu bingung dalam penyusunan kalimat dalam bahasa inggris. Serta, kapan dan dimana menempatkan kata bantu do dan does maupun artikele the, an, and a. Saya juga kesulitan untuk menentukan verb 1 , verb 2, dan verb 3, hal ini menyebabkan saya terkadang khawatir jika mau tampil di depan kelas.

Students 3: I have a problem with grammar; I am always confused when placing words in English. Moreover, when and where to place the words do and does and article the, an, and a. I also have difficulty determining verb 1, verb 2, and verb 3, this causes me to worry sometimes if I want to appear in front of the class.

EFL students' problems in grammar are very complex. The grammatical rules were often confused the students when they speaking English. Their problems is arranging the sentences and using grammatical pattern correctly. Furthermore, they confused to apply the rules in real communication.

d. Anxiety

Based on the interview, the EFL students stated that feeling anxiety was one of their problems in speaking English. It proves by looking at the students' statement in interview below:

Students 4: Selain saya kurang kosa kata, perasaan cemas sangat mempengaruhi keadaan saya, jika berhadapan dengan orang lain apalagi dengan dosen. ketika di dalam kelas, dosen meminta memberikan pendapat menggunakan bahasa inggris, pada saat itu saya gugup sekali, sehingga saya sulit sekali untuk berbahasa Inggris. Saya masih suka menyebut kata-kata sesuai dengan tulisannya, bukan cara bacanya.

Students 4: Besides I am lack of vocabulary, feeling anxiety affects my situation, when dealing with other people especially with the lecturer. When in class, the lecturer asks to give an opinion using English, at that time I was very nervous, so I found it very difficult to speak English. I still like to say words according to their writing, not how to read them.

Anxiety explained as the students often feel worry when the students get topic that not familiar for them.

e. Ashamed

Ashamed is the students' feeling that worried about making mistakes. Ashamed is caused someone to be constrained in speaking activities, if this problem continuously it is really to get out of this problem. This result came from the students' statement in the interview below:

Students 5: Iya ada, saya malu karena biasanya saya ditertawakan oleh teman-teman kalau saya menyebutkan kata-kata dalam bahasa Inggris tapi kata-kata yang saya sebut itu salah.

Students 5: Yes there is, I am ashamed because I am usually laughed by my friends when I mention words in English but the words I call are wrong.

Students 6: Kurangnya penguasaan kata dan jarang berkomunikasi dengan orang lain menjadi alasan saya malu ketika berbicara di depan umum. Jadi saat saya dapat tugas di depan kelas saya sangat malu. Saya berusaha untuk belajar secara mandiri dirumah kadang bicara didepan cermin sambil memegang buku.

Students 6: Lack of mastery of words and rarely communicating with others is the reason I am shy when speaking in public. So when I got an assignment in front of the class I was very ashamed. I try to study independently at home sometimes talk in front of a mirror while holding a book. 
Based on the interview above, the students' confirmed that they cannot handle their feeling when they communicate with others. It showed that, ashamed become factor that influence in speaking English.

f. Mother Tongue Use

The last problem that the researcher found was the use of mother tongue. This problem is exposed by the EFL students using mother tongue because the students feel that it easier than English and they use mother tongue to express themselves. It is description as follows:

Students 7: Karena beberapa kata saya tidak tahu maka saya lebih pilih menggunakan bahasa ibu untuk mengepresikan kata-kata yang saya tidak tahu daripada tidak mengatakan apapun. Sebenarnya, Ada rasa tidak nyaman ketika menggabungkan bahasa ibu saya dan bahasa inggris ketika di depan kelas.

Students 7: Because some words I don't know, I prefer to use my mother tongue to express word that I don't know than to say nothing. Actually, there is a sense of discomfort when combining my native language and English when in front of the class.

In this research, the researcher took mother tongue as Indonesian language and Luwuk language. The EFL students use mother tongue because their habit. They use mother tongue even they are in the classroom. When they want to ask and say something to lecturer, they use mother tongue. It caused EFL students feel comfortable to use mother tongue although in speaking class.

This research deal with lacks of vocabulary, worry about making mistakes in pronunciation, worry about making mistakes in grammar use, feeling anxiety and ashamed, the last mother tongue use. These were the factors causing the EFL students faced problems in speaking. The researcher was identified through their speaking problems. Through this research the researcher found six points of their problems, from nine respondents, six respondents found with some problems and the other three respondents were different.

The EFL students of English Education Study Program in Muhammadiyah Luwuk University have been taught English speaking from the first semester, but many students were still got many problems in communicating use English.

\section{Conclusion}

Based on result and discussion, the researcher concluded that the speaking problems faced by the students were lack of vocabulary, worry about making mistakes in pronunciation and grammar. The causes of problems faced by students in speaking were lack of practice in English, getting difficulties in using tenses, grammar rules and how to pronounce words well.

The students also had other problems related with feeling anxiety, and ashamed when communicating with friends and lecturer. Speaking skill should be increased by practicing on daily life without having anxiety and ashamed making mistakes. The last, the students prefer use their mother tongue in expressing themselves. It caused the students lazy to remember the English vocabulary, so they often include their mother tongue when they speak English. In other word, the students' mind about English is difficult causing the students lack of motivation to learn more about English.

\section{References}

Brown, H. D. (2001). Teaching by Principle and Interactive Approach to Language Pedagogy. New York: Longman Inc.

Burnkart, G. S. (1998). Spoken Language: What Is and How to Teach It. Retrieved 
BEEJ, e-ISSN 0000-0000, Vol. 1, No. 1, March 2020

December 19, 2019, from http://www.nclrc.org/essentials/speaking.goalsspeak.htm Heriansyah, H. (2012). Speaking Problems Faced by the English Department Students of Syiah Kuala University. Lingua Didaktika, 6 (1), 37-44.

Miles, M.B, Huberman, A. . (1994). Qualitative Data Analysis (2nd ed.). London: Sage Publication.

Richard, J.C. Renandya, W. A. (2002). Methodology in Language Teaching. New York: Cambridge University Press.

Sayuri. (2016). Problems in Speaking Faced by EFL Students of Mulawarman University. Indonesian Journal of EFL and Linguistics, 1 (1), 47-61.

Thornbury, S. (2005). How to Teach Speaking. England: Person Education Limited.

Ur, P. (1996). A Course in Language Teaching Practice: and Theory. Cambridge: Cambridge University Press.

Zhang, F. (2009). A Study of Pronunciation Problems of English Learners in China. Asian Social Science. 5(6): 141-146., 5 (6), 141-146. 